\title{
Towards a definition of "communication policy", "language policy", and "language planning"
}

Henning Bergenholtz

Department of Afrikaans and Dutch, Stellenbosch University, Private Bag X1, Matieland, 7602, South Africa. E-mail: hjbergen@sun.ac.za

Centre for Lexicography, Aarhus School of Business, Fuglesangsallé 4, 8210 Århus, Denmark. E-mail: hb@asb.dk

\section{The need for a communication policy, language policy, or language planning}

Ever since God saw fit to inflict punishment on those who built the tower of Babel, there has been a need for an interlingual language policy entailing language selection in order to achieve successful communication. However, even prior to the building of the tower, first God and later Adam - under God's tutelage - made use of an intralingual language policy when naming objects and concepts. In the beginning, God took responsibility for the naming:

And God called the light Day, and the darkness he called Night. And the evening and the morning were the first day. (Genesis 1.5)

After creating Adam, God made use of his emissary to name earthly phenomena:

And out of the ground the LORD God formed every beast of the field, and every fowl of the air; and brought them unto Adam to see what he would call them: and whatsoever Adam called every living creature, that was the name thereof. And Adam gave names to all cattle, and to the fowl of the air, and to every beast of the field; but for Adam there was not found a help meet for him. (Genesis 2:19-20) 
According to Genesis, the same universal language was used and understood by both mankind and animals for communicating between themselves and each other. In the first speech act that occurred after the naming of all known entities, the snake is recorded as persuading the only woman present to eat the forbidden fruit:

Now the serpent was more subtil than any beast of the field which the LORD God had made. And he said unto the woman, Yea, hath God said, Ye shall not eat of every tree of the garden? And the woman said unto the serpent, We may eat of the fruit of the trees of the garden: But of the fruit of the tree which is in the midst of the garden, God hath said, Ye shall not eat of it, neither shall ye touch it, lest ye die. (Genesis 3:1-3)

Genesis 3:1-3 indicates that language can be used for purposes of temptation. To prevent such misuse of the gift of communication, God might have decided to forbid all further communication, but he did not do so:

And the whole earth was of one language, and of one speech. (Genesis 11:1)

Neither did he choose to do so later, during the building of the tower of Babel, instead choosing to make communication between people much more difficult and sometimes impossible:

And the LORD came down to see the city and the tower, which the children of men builded. And the LORD said, Behold, the people is one, and they have all one language; and this they begin to do: and now nothing will be restrained from them, which they have imagined to do. Go to, let us go down, and there confound their language, that they may not understand one another's speech. (Genesis 11:5-7)

During the so-called "Pentecostal Wonder", mankind returned to the communication paradise requiring no interlingual language policy. People used different languages; nevertheless, everyone at the time was able to understand everyone else: 
Now when this was noised abroad, the multitude came together, and were confounded, because that every man heard them speak in his own language. (Acts of the Apostles 2:6)

However, the communication paradise did not last long: Non-believers grudgingly suspected that those capable of mutual understanding were drunk:

Cretes and Arabians, we do hear them speak in our tongues the wonderful works of God. And they were all amazed, and were in doubt, saying one to another, What meaneth this? Others mocking said, These men are full of new wine. (Acts of the Apostles 2:11-13)

Despite the fact that most linguists support people's intrinsic right to the integrity of their own language, all communities throughout the world urgently need to regulate their use of language in order to ensure that communication is possible and, at its best, also successful. Such language regulation, as expounded by linguists and communication scientists, is referred to variably as "language planning", "language policy", or both, and even at times as "communication policy".

In terms of lexicography, the fields of language planning, language policy, and communication policy lack clear and unambiguous terminology, in both their theory and practice. Not even the only dictionary containing the terms of one of the fields mentioned which is described by the author as "the dictionary of language planning terms" (Cluver 1993) - provides such guidance. Ironically enough, Cluver's dictionary actually serves as support for the "leave-your-language-alone" argument, as this dictionary contains purely descriptive reproduction: It provides definitions formulated by some of the best-known language planning scholars, relating how they have used the terms with their linguistic histories of antonymous use, but without related language usage norms.

This paper will recommend certain definitions and uses of the terms "language planning", "language policy", and "communication policy", rather than provide an overview of the fields. Little is known about the history of the term "communication policy", which appears only to have come into use in the early 1970s. The terms "language planning" and, to a 
certain extent, "language policy" have been discussed by Karam (1974), Cooper (1989:29_ 45), Cluver (1993), Ager (1996:1-28), and Bergenholtz and Tarp (2005). Historically, "language policy" is the older term, as it came into use at about the beginning of the 20th century. In Denmark, for example, the term "language policy" was used as early as 1921 to refer to (i) government regulation of language choice (the interlingual dimension) and (ii) regulation or judgement of language use (the intralingual dimension), as noted by Jarvad (2001:18). A more recent term for the same concept is "language engineering", which was first introduced by Miller (1950). Related terms, such as "glottopolitics", "language development", "language regulation", and "language management" ${ }^{1}$ tend to be used less frequently. One of the three main terms, "language planning", was introduced by Haugen (1959). According to Cooper (1989:29), Haugen noted that he became familiar with the term in a seminar presented by Uriel Weinrich two years earlier. It is surely no coincidence that it was a Scandinavian linguist who introduced this term - in that part of the world, there is a longstanding, strong tradition of government regulation of language. Best known is Ivar Aasen's development of a "new" Norwegian language in the second part of the 19th century, created in a personal struggle for a new language on the basis of a dialect in Western Norway (now called nynorsk). Haugen's papers about language planning inevitably received a significant degree of attention when published in the country where Hall's propounding of the principle of leaving language alone was the indisputably overpowering linguistic method of the day. Only such a historical context can explain a title such as "Can language be planned?" (Rubin and Jernudd 1971a). Language can indeed be planned, and has been since Old Testament days, as can be seen in the presence of myths in that part of the Bible. In the field of linguistics, the idea of language planning was first mooted in German literature in $1640^{2}$ (cf. Bergenholtz 1991). Under the overwhelming influence of structural and descriptive linguistics in the USA during the 1950s and 60s, non-descriptive linguistics was put on the back burner (cf. Fishman 1974a:25).

\section{A paradox and the usual lack of clarity}

It is difficult to explain the absence of interdisciplinarity between linguistics and communication science in terms of the scientific discussion about language policy and communication policy. Similarly, the absence of intradisciplinarity between many of the linguists dealing with language planning and language policy is also problematic. Paradoxically, no explicit relationship exists between contributions to the field of 
communication policy, on the one hand, and those made to the field of language policy or language planning, on the other.

According to tradition, first God and later Adam gave names to entities. Such naming seems to have indicated a clear 1:1 relationship between expression and content, which later no longer was the case, neither for groups of languages nor for specific languages. Terminologists and specialised lexicographers generally complain about the lack of clarity in most scientific language, which they attempt to solve by developing specialised dictionaries and terminological databases, which, however, themselves may be inadequate (cf. Cluver's 1993 attempt). Terms in the fields of language planning, language policy, and communication policy should, however, prove the exception, due to their having been coined and used by experts in the field of language regulation. So far, however, proposals of terminology - of which the most important one has been that of Karam (1974) - have failed to distinguish clearly between interlingual and intralingual regulations, and Cooper's (1989:31) four questions regarding who, what, for whom, and how are not reflected. Lack of clarity, therefore, characterises most existing definitions, as exemplified by the following one of "language policy", in which government decisions prescribe one kind of language policy and non-governmental regulations another:

In this report, the term is used to describe the collection of laws, rules and stipulations that determine the status of a language, including rights compared to other languages, and that determine the right or the correct language. The term is also used to describe the variety of initiatives that play an active part in promoting, strengthening and protecting a language. (Jarvad 2001:18) [my translation - HB]

Similarities do exist between definitions of "language planning" - amongst others, a failure to refer to "language policy". The reason for language policy being (too) closely connected to government decisions ${ }^{3}$ is perhaps easier to explain than this apparently inexplicable paradox.

The second half of the $20^{\text {th }}$ century saw the formation of a number of new composite expressions derived from the term "policy", such as "educational policy", "children's policy", "women's policy", "environmental policy", and "immigration policy". The new derivations were related to key areas in the political decision making processes of international, national, 
or local authorities and also encompassed the terms "language policy" and "communication policy". Since the late 1980s, the scope of such derivations has broadened to include aspects such as planning and decision making that occur in companies, organisations, schools, and other non-political groups, as can be seen in, for example, "senior policy", "smoking policy", "alcohol policy", and "stress policy". Along with this development, the scope of older, purely political terms has also been broadened to include planning and decision making in such bodies. Such a development, which is social as well as linguistic, has not only occurred in the Danish language or in Denmark itself.

Speakers of certain languages seem to prefer certain terms. For example, Danish speakers seldom use the Danish equivalent of "language planning", preferring the Danish equivalent of "communication policy" and, to a lesser extent, "language policy", according to an Internet search using the Google search engine (13 January 2006):

- $\quad$ sprogplanlcegning (=language planning)

- $\quad$ sprogpolitik (=language policy)

- $\quad$ kommunikationspolitik (=communication policy)

The same trend exists in the use of German, though German speakers rarely use the German equivalent of "language planning" for the discussion of language and communication problems; they prefer the German equivalent of "communication policy":

- Sprachplanung (=language planning)

- Sprachpolitik+Sprachenpolitik (=intralingual+interlingual language policy) 134.100

- $\quad$ Kommunikationspolitik (=communication policy)

As a number of Google searches for the English terms reveal, "language planning" and "communication policy" occur with approximately the same frequency, whereas "language policy" is definitely the most used term:

- language planning

206.000

- language policy

- communication policy 
As witnessed, the Danish terms "sprogpolitik" and "kommunikationspolitik" occur with almost the same frequency in Danish Internet texts, whereas the term "language policy" is used almost twice as frequently as is "communication policy" in English texts. The terms used can therefore be seen to occur with approximately the same frequency as those for other forms of policy, such as "alcohol policy", which has a frequency of occurrence of 603,000. A closer look at the individual texts, however, reveals with remarkable clarity that the occurrence of both terms in the same text is extremely rare. Simultaneous occurrence could only be located in 370 texts on the entire Internet. Relatively few of these texts attempted to define or relate the two terms to each other. In texts on language policy, relatively unmotivated references may occur to a "corporate communication policy", such as in a review of the FAO language policy (Food and Agricultural Organisation of the United Nations 1999). Similarly, texts on communication policy tend to allude to "language policy", without discussing the term as such. This trend corresponds with the division into two distinct groups of those with an active interest in the subject. While one group - consisting of politicians, the public media, linguists, and certain divisions of companies - discusses language policy without referring to communication policy, the other group - comprising business economists, communication scientists, and other divisions of companies - discusses communication policy without referring to language policy. ${ }^{4}$

Exactly the same trend manifests itself in Danish and Swedish government proposals on language policy. Such proposals are devoid of the term "language planning" and rarely contain the term "communication", tending to use "language" instead. Similarly, no reference is made to communication policy, but only to language policy. Nevertheless, ministries, departments, and local authorities have implemented a multiplicity of communication policies (cf. Møller Nielsen 2003). The term "communication policy" does not occur in the actual legislation, whether in the form of acts or executive orders. Although a demand for legislation on communication policy has been expressed (Rosholm 2002), such a demand appears to have been made for purposes of publicity rather than for a more serious, or even realistic, reason. Legislation on language policy does indeed already exist or is currently being prepared in several countries, including Denmark (Kulturministeriet 2003) and Sweden (Utbildnings- och kulturdepartementet 2005). ${ }^{5}$ Similarly, the term "communication", but not "communication policy", occurs in a South African proposal: A fine distinction exists 
between oral and written text and between internal and external national and international communication, but the appropriate term for referring to a communication policy is "language policy", as can be seen in the following excerpt:

1. Language policy on internal oral communication for all government structures By consensus, all government structures must agree on their working languages for internal oral communication, intra and interdepartmentally, unless other rules apply, and subject to the proviso that no person shall be prevented from using the language of his or her preference, at any given time.

2. Language policy on internal written communication for all government structures $[\ldots]$

3. Language policy on external oral communication for all government structures $[\ldots]$

4. Language policy on external written communication for all government structures [...]

5. International communication International communication on the part of government will normally be in English or in the preferred language of the relevant country.

(Language Policy and Plan for South Africa 2000)

Common to the proposals from Denmark, Sweden, and South Africa is the lack of definitions for the basic terms, as the proposals merely describe a number of problems and possible solutions to the problems. The Swedish proposal of 29 September 2005 primarily focuses on interlingual measures, only mentioning towards its close intralingual issues relating to the Swedish language. The South African proposal discusses only interlingual issues, entirely omitting any reference to intralingual ones. Governments' concern with language policy is reflected worldwide in the media, not just in South Africa and Sweden. Forming a general view of all journalistic contributions made in the newspapers of so many different countries seems practically impossible. The attendant public debate not only involves government proposals and issues relating to language policy on a national level, but also issues relating to language policies of particular companies and international organisations, such as the EU. However, language policy and language planning are not referred to in the same breath in documents about communication policy, such as in the proposals of the South African Task 
Group on Government Communications (Comtask) accepted by the Cabinet on 8 October 1997 (Comtask Report 1996).

The English language tends to dominate all discussions of language policy. In English, the distinction is made between "policy" and "politics", whereas languages such as Danish, German, French, Spanish, and Dutch tend to use only the term "language policy" when referring to language theory, as well as to language planning and implementation - cf. the Spanish "política lingüística", the French "politique linguistique", and the Danish "sprogpolitik". In this paper, the term "language policy" will be used as a blanket term for the German concepts of 'Sprachpolitik' and 'Sprachenpolitik' (cf. Bergenholtz 2004). This decision is based on a language policy related problem. When you use a language, you do not only use the single expressions of that language but also their culture-bound meanings. For speakers of languages other than English, having to write in English does not necessarily entail importing English constructs into their own first languages (such as Danish, Spanish, or French), or losing unique language differentiation (such as in the case of German). The use of English by speakers of languages other than English may be unconventional, while not, as such, being incorrect. However, such use of English terms would change the meaning attached to certain concepts, as well as being inappropriate for purposes of scientific argumentation, which relies on exactness of expression to ensure clarity of meaning. In other words, the problem as to which language concept system will dominate belongs to the field of scientific language policy (cf. Phillipson 2003:139-174). I choose to use the term in the way I find more appropriate, namely the way it is used in non-English languages such as Spanish, French, and Danish.

\section{Who plans what for whom and how?}

The list of questions taken from Cooper (1989:31-42), ironically enough, misses the most important question: Why? Though being of relatively minor importance to language planners and language politicians, the solution to such a question may be difficult to uncover for most linguists. The major linguistic textbooks have - since the predominance of romantic linguistics in the 1820s, followed by structural linguists in Europe, still later by the behaviourists, and most recently by the hyper-descriptive American linguists - been descriptive: The main responsibility of a linguist is to describe language use, not to prescribe what is appropriate. No language phenomenon that is accepted and used by a native speaker 
can justifiably be regarded as incorrect, as can be seen in the entry sprogrigtighed "language correctness" in the Danish Dictionary of Linguistics (1996). In the American tradition, nondescriptive linguists are sometimes labelled as reactionary or even dangerous. Natural language change is regarded as positive, whereas non-natural change is regarded as negative:

For change that comes spontaneously from below, or within, our policy should be, Let your language alone, and leave its speakers alone! But other forms of language manipulation have other origins, other motives, other effects, and are far more dangerous. (Lakoff 1990:298)

Such a judgement appears to have overtones of a religious credo: The only value in linguistics appears to lie in its recognition of spontaneity in language. Cameron (1995:20) enquires as to whether no other important values exist in linguistics, such as truth, beauty, logic, or utility. Both Lakoff and Cameron open up for debate the attempt to forbid or recommend certain aspects of style, certain grammatical constructions, words, spellings, or pronunciations. The value of such intralingual regulations for language usage can lie in the possession of a certain brand or a friendly image, as is so often the case with companies or organisations (cf. Bergenholtz, Bisgaard, Brunsborg, and Kwichmann 2003). Danish courts also recognise the importance of applying a set language policy throughout the organisation:

The Danish Courts have a vision of being a respected and trustworthy organisation operating at the highest quality, service and efficiency level. However, the professional quality must also be mediated by means of use of clear, understandable and modern language. (Language Policy for Danish Courts 2003:1) [my translation - HB]

Depending on the other factors (viz. who, what, with whom, and how) involved in the communication process, values differ greatly. In order to avoid ideological conflict, special language policies may be developed for schools, universities, and organisations. Use of certain words or expressions, which are perceived as being derogatory, may be forbidden or strongly discouraged. Examples of such words or expressions are kaffirs (an offensive term sometimes used to refer to black people in South Africa) and fuck you din luder (a Danish expression, literally meaning "fuck you, you whore", sometimes used by an Arab male immigrant to order a Danish woman to leave him alone). Such policies are usually justified in 
terms of value requests, such as "Be politically correct" or "Avoid use of verbal insults that may lead to violence". Such instructions typify the language policies of Danish primary schools.

No strong counter-arguments to the interlingual dimension of language regulations exist that can in any way be equated with those opposing intralingual language issues. Webb (2002:3) argues that "there are a number of serious educational, economic and political problems in the country [South Africa - HB]; that language plays some role in these problems; and that the problems will not be resolved in a 'natural' way, 'sorting themselves out"'. The reasons for such linguistic interventions are based on values such as democracy, human rights, and the protection of linguistic diversity, as can be seen in the following excerpt from the draft South African language policy:

This language policy is intended as an enabling framework for promoting South Africa's linguistic diversity and encouraging respect for language rights within the policy framework of building and consolidating a united democratic South African nation. (Language Policy and Plan for South Africa 2000:1.1)

Although the issue of values does not form the main topic of the ongoing language policy and planning debate, it is central to discussions revolving around communication policies. In the following quotation, the mentioned values appear to be of negligible importance to the central theme. Furthermore, no explanation is provided of what is meant by "sound principles", nor are guidelines provided on how to communicate effectively or appropriately within the said environment:

The Museum recognises the link between internal and external communication and strives to ensure communication throughout the Museum is based on sound principles. [...] Effective communication plays a significant role in building the success of the Museum. Communicating appropriately converts potential visitors, users and supporters to actual visitors, users and supporters. (National Museum of Australia 2005) 
In contrast to the above, an example of a very clear and comprehensible communication policy outlining the participants, purposes, and communication channels involved is the communication policy of the European Court of Auditors. The overall description of the ambit of the Court's communication policy is stated as follows:

Communication policy covers the process of communicating the European Court of Auditors' role, work and the results it obtains to the outside world. (European Court of Auditors 2002)

After this brief introduction, the communication policy elaborates on the overall description first provided by naming the three main groups of those impacted by the policy: other institutions and member states, the public, and the media. The next section of the communication policy describes the purpose of the policy as

following the principles of openness and transparency as well as to ensure that the results of the Court's work are known and understood and to account to the citizens of the Union for the Court's work. (European Court of Auditors 2002)

Furthermore, the communication policy is stated as being intended to raise awareness of the Court and to ensure that audit reports are presented clearly and comprehensibly. The Court's website is cited as serving as the most important source of information on the Court. In the light of ever-expanding access to the Internet, such an approach helps to raise awareness of the Court, as well as facilitating the dissemination of information on the Court and its proceedings.

Another example of a well-formulated communication policy is that of the Danish Medicines Agency (2005), in which communication is described as "a strategic activity included in all significant decisions at the Danish Medicines Agency". The communication policy is presented as a set of guidelines aimed at supporting the Agency's objectives in both internal and external communication. In this way, communication is awarded a high priority, with use of the wording "strategic activity" indicating that communication is, at least in part, seen from a business economics perspective by the Agency. The keywords of the policy, which 
apply to both internal and external communication, are active, open, trustworthy, responsible, and service oriented.

\subsection{Who?}

Many contributions to language policy and planning, including those of Hartmann and James (1998:81), Coronel-Molina (1999), and Webb (2002:31), in principle agree with the assertion "that language policy decisions are actually political decisions that can only be taken by national governments" (Language Policy in Africa 1997:157). However, it should be added that such decisions may also be subject to intervention from corporations, international organisations, families, and even individuals. More in line with the reality of language planning/policy are examples such as Shell's language policy in Malaysia or the choice made by a Finnish-British couple living in England regarding the language they should use for communicating with their child (Jernudd 1973:18ff.). Whereas the former is an example of corporate language policy/planning, the latter reflects family intervention in this regard. Both language planning and language policy can therefore be determined by governments, government-authorised agencies or bodies, local authorities, international and national organisations, a group of people, a family, or even a single person. In each case, a decision is made regarding the language used (Jernudd 1973:19). Such decisions are usually imposed top-down (by bodies such as the government or management), though pressure may in certain instances be exerted from the bottom up. An example of the latter is where a Danish immigration organisation publicly demanded information brochures from a private insurance company (Politiken 2006-02-04).

\subsection{What?}

In answer to this question, Cooper (1989:31-5) provides a peremptory though unfulfilling discussion of status, corpus, and acquisition planning, the most common components of language planning. A more realistic view of the object of language planning/language policy/communication policy should be far broader and more detailed. Diverse aspects of communication can be chosen or supported from among the following examples, which are taken from different communication policies and language policies (for details and references, see Bergenholtz and Johnsen 2006):

(i) communication types (verbal or non-verbal, e.g., sign language) 
(ii) communication channels (TV, radio, trade fairs, newspapers, e-mails, letters, websites, blogs, text messages, etc.)

(iii) communication venues (meetings, assemblies, trade fairs, etc.)

(iv) the level to which the communication policy should apply (international, national, regional, etc.)

(v) the communication rules for the various participants (board of directors, customers, managers, etc.)

Language policy and language planning usually presuppose, or should presuppose, some or all of the above-mentioned elements. An interlingual language policy should involve some of the following interlingual relations as a choice of, or as support for, the policy concerned:

(i) one or more languages for communication channels (TV, radio, trade fairs, newspapers, e-mails, letters, websites, blogs, text messages, etc.)

(ii) one or more languages for communication venues (meetings, assemblies, trade fairs, etc.)

(iii) the level to which the interlingual language policy should apply (international, national, etc.)

(iv) one or more languages for communication products (text types, actual texts, text parts)

An intralingual language policy or language planning presupposes the above-mentioned decisions and involves (i) the choice of level to which the intralingual language policy should apply (international, national, etc.), and (ii) the recommendations or rules concerning the linguistic presentation of communication products (text types, actual texts, text parts).

\subsection{For whom?}

Whether a national language policy should be applied to all citizens of a country is debatable, just as it is debatable whether a corporate language policy should, in fact, apply to all participants in all internal and external, as well as to all outgoing and incoming, communication of a company. Many different aspects have to be taken into account when providing the answer to questions such as these which have so many varying ramifications. The question of punishment or the possibility of a negative reaction if someone in the intended group does not follow the prescribed policy guidelines, also has to be taken into 
account. In most cases, a corporate language or communication policy should be applied to all internal and outgoing communication, but not to all incoming communication, meaning to the communication of all those employed by, or belonging to, the relevant organisation, nation, or group. For example, the communication policy of the European Court of Auditors (2002) should be adhered to by all employees of the Court. Similarly, Danish language law enacted in September 1997 requires that the prescribed language policy must be adhered to by all government employees, as well as by all other employees, students, and pupils working for, or studying at, institutions that receive financial support amounting to $50 \%$ or more of all their institutional costs. In practice, no employee may be punished if (s)he fails to follow the very strict and exact orthographical and inflectional rules (see examples of such in Bergenholtz 2003). However, pupils and students may be penalised by giving them low marks.

Unlike language policy, which, as has been seen, solely concerns outgoing communication, communication policy may also address the issue of incoming communication. For example, the Director Communication Policy of the American bio-research company, Applera (2005), expressly states that "stockholders and other interested parties may communicate directly with the Board or the non-management directors" and that all such communication should be in writing and directed to the corporation's secretary. Such a policy overtly indicates openness and a willingness to communicate with the stockholders concerned.

\subsection{How?}

This question is usually discussed in terms of description and prescription - a necessary but not sufficient methodical view, because the difference between description and prescription cannot be explained as a distinction between "is not to be followed; it is only a description of real communication" and "is to be followed, and the rules differ from those used in normal communication". This discussion of an exact definition of "description", "prescription", and "proscription" shall not be repeated here, but I will pay attention to the following arguments: The distinction has to be drawn between different types of description and different types of prescription (Bergenholtz 2003). And, first of all, we need a concept for that kind of selective description often used in dictionaries and grammar books where you are told about different uses but only one of them is recommended. Such an approach relates closely to the proposals of Tauli (1974), as well as to Unesco's recommendations regarding standardisation of written 
language (Unesco 1953). Any uniformity in writing and the use of words or grammar construction is advantageous, though attempts to standardise according to existing language use are advisable. The same method is followed regarding proposals for use of the terms "language planning", "language policy", and "communication policy" made in this paper.

\section{Types of definitions and terminological use}

A great number of theoretical contributions and concrete language and communication policies were consulted in an attempt to systematise the use of terminology in these documents. The different contributions studied have been categorised based on their use and/or definitions of the expressions "language policy", "language planning", and "communication policy", focusing on who and what is involved. The different categories have been assigned specific labels which indicate the expressions used in the contributions concerned. These labels are presented as the headings of sections 4.1 to 4.10 .

\subsection{Use of only "language policy"}

The term "language policy" is the only one used in the contributions in this category - no relationship is established to the terms "language planning" and "communication policy" or to their use. In certain cases, the term may be used only for intralingual regulations (such as in the case of the Language Policy for Danish Courts 2003), while in other cases, the term may be used only for interlingual regulations (e.g., de Cillia 2003); usually though the term is used for both (e.g., Committee on the Swedish Language 2002). Geographically speaking, most such contributions originate in European countries where English does not form the first language of choice (cf. the above-mentioned data relating to use of the Danish and German languages).

\subsection{Use of only "language planning"}

The term "language planning" is the only one used in the contributions in this category. Whereas expressions such as "policy decision" or "political participation" may be mentioned, the terms "language policy" and "communication policy" are not used. Some scholars mention only intralingual aspects (Haugen 1959:8, 1969:701), whereas others mention only interlingual aspects (Fishmann 1974b), though usually they consider both inter- and intralingual dimensions (Tauli 1968:27, 1974:56; Hartmann and Stork 1972:126; Cooper 1989:45; Johnson and Johnson 1998:184). Some of the terminological proposals are quite 
problematic, such as Hartmann and Stork's (1972:126) conceptualisation of "language planning" as being synonymous with "prescriptive linguistics". Tauli's (1974:56) distinction between the theory and practice of language planning seems to be relatively relevant, as it is reasonably similar to the distinction made between "language planning" and "language policy", as proposed by Richards, Platt, and Platt (1992:203). A similar distinction is found in some of the South African proposals that "language planning" be used for the theory and "language plan" for a concrete language policy (e.g., the Language Policy and Plan for South Africa 2000).

\subsection{Use of only "communication policy"}

Only the term "communication policy" is used in the contributions that fall into this category, excluding the terms "language policy" and "language planning" (Communication Policy for Danish Courts 2003; ${ }^{6}$ Applera 2005; Centre for Deaf Studies 2005; National Museum of Australia 2005; Kotler and Keller 2006:534-562). In this group of contributions, Rosenmeier (2005) is the exception, using both the terms "communication policy" and "language policy" without clearly distinguishing between them or defining either term. In the above-mentioned contributions, as well as in most of the other contributions to concrete communication policies, the objective is neither the choice of one or several languages (intralingual selection), nor the proposal of rules for intralingual language usage, but rather more general, sometimes very abstract, proposals or regulations regarding (i) more effective communication; (ii) the choice of communication channels; (iii) security proposals using special channels (e.g., e-mail communication); or (iv) a choice between linguistic and nonlinguistic communication.

\subsection{Use of only a combination of "language planning" and "language policy"}

A statistical overview of the contributions that fall into this category reveals that both "language planning" and "language policy" occur most frequently, so that the different terminological approaches are unclear. The need for terminological planning or policy is pressing in these contributions. None of these contributions mentions communication policy.

\subsection{The complementary use of "language planning" and "language policy" (A)}

Whereas "language planning" is used for intralingual regulations, "language policy" is used for interlingual regulations (Hartmann and James 1998:81). This distinction is also seen in 
some Dutch and Afrikaans dictionaries, but not in contributions from language policy/planning specialists; it may, nevertheless, influence the terminological use in lexicographical contributions. For example, see "the use of a language" (singular) in the first and "use of languages" (plural) in the second definition:

language planning The totality of activities aimed at regulating the use of a language, often linked to national policies. Such control is usually imposed centrally by governmental or quasi-governmental agencies, such as ACADEMIES or language policy bureaus. Measures may include banning FOREIGNISMS, coining NEOLOGISMS and TERMINOLOGY, controlling the media and redirecting education policies.

language policy A set of governmental decisions on the relative priorities of the use of languages in a state, for the purpose of employment, education, etc., which can influence the number and types of REFERENCE WORKS produced and used.

(Hartmann and James 1998:81)

\subsection{The complementary use of "language planning" and "language policy" (B)}

Whereas "language planning" is used to describe the theoretical approach, "language policy" is used to describe the practice. The contributions in this category use the two terms in a way similar to Tauli's (1974:56) distinction between the theory of language planning - which in this category appears merely as "language planning" - and the practice of language planning - which appears as "language policy", such as in the case of Sandøy and Vikør (1977:12), Richards, Platt, and Platt (1992:203), Fettes (1997:14), and Webb (2002: 39-41). "Language planning" covers theoretical and methodical considerations, whereas "language policy" covers both control and further development of language planning models. This distinction corresponds to the differentiation between terminology and terminography or between metalexicography and practical lexicography, the borderline between the subfields often being relatively indistinct. In the case of the use of "language planning" for theory and method, as well as the use of "language policy" for practice, the same form of lack of clarity exists due to the absence of a distinct borderline, cf.:

Therefore language planning in this wider sense must be linked to the critical evaluation of language policy: the former providing standards of rationality and effectiveness, the latter testing these ideas against actual practice in order to promote 
the development of better (more sophisticated, more useful) language planning models. (Fettes 1997:14)

\subsection{The language policy as part of language planning}

Such terminological use is in some cases related to the complementary usage of "language planning" and "language policy" referred to above, except that the contributions in this category use "language planning" as a general term for all kinds of language regulations, and "language policy" when governments and other official authorities are involved (e.g., Rubin and Jernudd 1971b:xvi-xiii; Eastman 1983:7-16; Crystal 1992:220; Cluver 1993:31-36; Kaplan and Baldauf 1997:3; Kamwangamalu 2004:243; Wikipedia 2006), as in:

Language planning refers to deliberate efforts to influence the behaviour of others with respect to the acquisition, structure, or functional allocation of language. Typically it will involve the development of goals, objectives and strategies to change the way language is used in a community. At a governmental level, language planning takes the form of language policy. (Wikipedia 2006)

\subsection{Language planning as part of a language policy}

This group of contributions uses the terms in diametrically opposing fashion to that mentioned in section 4.7: they use "language policy" as the main term, whereas "language planning" is regarded as part of "language policy" (e.g., Sibayan 1974:222-228; Ager 1996:28; Trask 1997:127). The researchers responsible for such contributions distinguish between the terms in different ways. For Trask (1997:127), language planning is an intralingual field, whereas language policy is both intra- and interlingual, as in "the form of a language" (singular) in the definition of "language planning" below and "one or more languages" (singular and plural) in the definition of "language policy":

language planning Making deliberate decisions about the form of a language, such as choosing among competing forms and inventing new vocabulary. This is most often carried out on some kind of official basis.

language policy An official government policy regulating the form, teaching or use of one or more languages within the area controlled by that government.

(Trask 1997:127) 
For other researchers, "language policy" is the collective term for different subfields, including language planning, e.g.:

Language policy: the contributions of sociolinguistics, policy studies and language planning. (Ager 1996:28)

\subsection{The synonymous use of "language planning" and "language policy"}

In practice, the impression is created that most scholars use the two terms alternately without making a clear-cut distinction, if any at all, between them. At least one example explicitly states that the two terms are regarded as synonymous:

No distinction is made in this paper between language "policy" and language "planning". (Grin 1996:37, footnote 10)

Such terminological use fairly closely equates with that in the following proposals, albeit vice versa regarding the use of "language policy".

\subsection{Use of "communication policy" together with the synonymous use of "language policy" and "language planning"}

The internationally well-established use of "communication policy" occurs alongside "language policy" in the contributions in this category. Although the term "communication policy" is sometimes seen as having a similar meaning to "language planning" and "language policy", I propose a distinction in its use in order to avoid terminological confusion in relation to future contributions to the field of communication policy. The issuing of communication policies by various institutions, organisations, and companies makes it unsurprising that such policies are adapted to the needs of the particular institutions, organisations, and companies concerned. However, an emphasis on values, openness, transparency, and comprehensibility appears to recur, with the only exception being the electronic communication policy, which emphasises cautions and restrictions. Furthermore, the examples studied show that communication policies may apply to written as well as to non-written, and even to non-verbal, communication, and also to traditional written and 
electronic communications. Unlike language policies, communication policies may apply to both incoming and outgoing communication.

The following are examples of terms that are used as synonyms or near-synonyms for "communication policy": "communication guidelines and standards", "information policy", "communication strategy", "action plan for communication", "openness policy", and "media policy". To make an exact distinction between these terms would exceed the scope of this paper; therefore, "communication policy" is taken as a generic term for the listed synonyms and near-synonyms. Beside "communication policy", we need one, and only one, term for inter- and intralingual language regulations. I prefer "language policy". In case of use of "language planning", the term has to be regarded as replacing "language policy", in order to avoid confusion. Only one of the two terms should be used together with "communication policy".

\section{Proposed definitions}

The preceding discussion and following definitions are aimed at the meta-level of scientific discussion of the fields of communication policy, language planning, and language policy. Under some of the recommended terms, ${ }^{7}$ I have listed expressions that appear to be used as synonyms for my term. The distinction between the theory and the real and concrete communication policies in some of the above-mentioned proposals is expressed in terms of "theory of language planning" in contrast to "language planning" (Tauli 1974:56) or in terms of "language planning" in contrast to "language policy" (such as in Fettes 1997:14). The most convincing terminological use seems to exist in the distinction between "language policy" and "language plan" (Language Policy and Plan for South Africa 2000). In international terminology, however, such a clear distinction is not found, as "language policy" is used for the theory and methodology, and the results are also called "language policy". I would propose the adoption of the term "language plan" for the results and "language policy" or "language planning" for the theory. The sum of all kinds of communication and language policies should be called a "communication and language plan".

\section{General communication policy}

= general language policy

= general language planning 
A general communication policy involves the deliberate control of an organisation's internal and external communication in order to optimise the functionality of the organisation, including its product development and sales. Usually, a communication policy takes into account the values and vision of the organisation concerned. A general communication policy is language-independent and is usually issued by, and applies to, companies, organisations, or sub-national authorities.

Language-independent general communication policies may also be issued by large international organisations, such as the UN, the EU, and NATO. In some cases, however, such a policy may also apply to an entire state, as can be seen in the case of certain African countries, such as Senegal and Tanzania (Tanzania 1997; Bathily 2005). International organisations and large companies often include a general description of their basic values in their language policies. Normally, however, the term "communication policy" does not include consideration of the value system entrenched in the company's or organisation's language policy.

The result of a general communication policy should be called "general communication plan".

\section{Specific communication policy}

= specific language policy

= specific language planning

A specific communication policy involves general or thematic requirements or prohibitions concerning particular forms or channels of communication or a prohibition against acquiring particular information or documents. Such prohibitions include requirements concerning general or limited access to, or use of, specific types of information.

Parts of a specific communication policy may apply not only to employees of the organisation or authority involved, but also, or solely, to enquiries made by customers or citizens. Thus, communication policy differs from language policy, which is always directed at the internal or external communication of employees, members, or students. Whereas a general communication policy rarely applies to states, several examples of specific communication policies on a state level can be found, particularly in dictatorships. Such 
communication policies may include the prohibition of flyers, phone calls to foreign countries, or use of the Internet. Examples of such communication policies can also be found in some existing language policies.

The result of a specific communication policy should be called "specific communication plan".

Interlingual communication policy should be referred to as "interlingual language policy", and intralingual communication policy should be referred to as "intralingual language policy".

Following from this definition of "communication policy", we arrive at a definition of the term "language policy" (and "language planning") that should be free of the flaws and inadequacies inherent to the aforementioned definition. In this regard, a number of synonyms will be listed in accordance with the terminology used in various theories and practices. It should be noted, however, that many language policies contain elements which we have classified as being a part of communication policy. In such language policies, the elements form an intrinsic part of the language policy, taking one of the following two forms:

(i) The basic values of a language policy and language planning, which should be referred to as "general communication policy", or

(ii) The selection of communication types, communication channels, and the use of nonverbal communication, which should be referred to as "specific communication policy".

Despite this being the case, whereas the terms "language policy/language planning" and "communication policy" may concern the promotion of different verbal and non-verbal languages, they differ in the sense that "communication policy" may also include guidelines on the selection and use of non-verbal languages. However, the term "language policy/language planning" refers solely to the selection and use of verbal communication forms in different contexts and may therefore be defined as follows: 


\section{Language policy}

$=$ language planning

"Language policy" - which refers to the deliberate control of issues pertaining to language concerns (i) relationships between languages, consisting of interlingual relations, on the one hand, and (ii) issues specific to one language, consisting of intralingual concerns, on the other. Though a language policy may form part of a communication policy, the existence of a communication policy is not a prerequisite for the existence of a language policy. The result of a language policy should be called a "language plan".

\section{Interlingual language policy}

$=$ status planning

$=$ interlingual communication policy

An interlingual language policy is the clear and deliberate choice, recommendation, or promotion of one or more languages. The result of an interlingual language policy should be called an "interlingual language plan".

\section{General interlingual language policy}

= general interlingual language planning

$=$ status planning

= general language policy

= language selection

A general interlingual language policy involves language selection, entailing the selection of certain languages at the expense of others. The result of a general interlingual language policy should be called a "general interlingual language plan". A language plan such as this could result in the production of bilingual or polylingual dictionaries in the selected or supported languages.

\section{Specific interlingual language policy}

$=$ specific interlingual language planning

$=$ status planning

= language promotion

A specific interlingual language policy serves as a protectionist language policy that prescribes the promotion of one or more languages, either by means of language-directed 
legislation or by means of financial and political support for certain organisations that promote a particular language or culture. Language-directed legislation concerning both verbal and non-verbal languages primarily applies within the country that promulgates the legislation in question. Organisations promoting a particular language or culture are supported in order to promote or increase the knowledge and use of the language in question, primarily in foreign countries.

The result of a specific interlingual language policy should be called a "specific interlingual language plan". The result of such a language plan can be the production of bilingual or polylingual dictionaries in the selected or supported languages.

\section{Special form of specific interlingual language policy}

$=$ special form of interlingual language planning

$=$ linguistic hegemony

A special form of specific interlingual language policy is a hegemonic language policy, involving an opposition to one or more languages in favour of one or more other languages. The result of a specific form of interlingual language policy should be called a "special form of interlingual language plan".

\section{Intralingual language policy}

$=$ intralingual language planning

An intralingual language policy is the choice or recommendation of, the warning against, or the banning of certain linguistic constructions, collocations, phrases, or words in a particular language. The result of an intralingual language policy should be called an "intralingual language plan".

\section{General intralingual language policy}

= general intralingual language planning

= communication-optimising language policy

$=$ style selecting language policy

= language guide

$=$ manual of style

$=$ style book 
= language hygiene

A general intralingual language policy involves stylistic selection, meaning a clear and deliberate choice or recommendation of specific stylistic aspects or rules pertaining to a particular language. The result of a general intralingual language policy should be called a "general intralingual language plan". A general intralingual language plan may result in the production of style guides or handbooks for language use.

\section{Specific intralingual language policy}

$=$ specific intralingual language planning

$=$ linguistic units selecting language policy

$=$ prescriptive linguistics

= language hygiene

= corpus planning

A specific intralingual language policy involves the selection of linguistic units, meaning a clear and deliberate choice or recommendation regarding specific grammatical constructions, words, or word forms in a particular language. The result of a specific intralingual language policy should be called a "specific intralingual language plan". Such a language policy may result in the production of dictionaries or grammars.

\section{Special form of specific intralingual language policy}

$=$ special form of intralingual language planning

$=$ purism

$=$ puristic language policy

= ideological language policy

= language hygiene

A special form of specific intralingual language policy is a puristic language policy based on a particular historical, moral, or political perception of "proper language", which results in the prohibition of, or opposition to, certain grammatical constructions, words, or word forms in a particular language. The result of a special form of specific intralingual language policy should be called a "special form of intralingual language plan". Such a language policy may result in the production of handbooks or specialised dictionaries. 
The above description of the relationship between "communication policy" and "language policy" serves to emphasise the fact that the formulation of a language policy should presuppose the existence of a communication policy. The statement, however, needs further elaboration on two accounts. Firstly, the statement primarily applies to intralingual language policies. Secondly, the reverse is also true, namely that a communication policy should always be supplemented by a language policy, albeit, in some cases, only an intralingual one. Such a deduction not only holds true for actual communication policies, but also for theoretical considerations. Furthermore, such a deduction means that contributions on communication policy based on business economics or communication sciences should take into account not only intralingual theoretical advances but also, to a certain extent, interlingual theories in the field of language policy.

\section{Back to Paradise or Pentecostal Wonder?}

Returning to Paradise and acting as God and Adam did during the first nomination of terms for inclusion in a universal language is impossible. One can only guess as to whether the Pentecostal Wonder might have provided a fitting solution in terms of providing the right and intended meaning for all participants in the communication process, despite their using the same term in very different ways. The proposal of definitions in this paper may be compared with the selection of animals and birds for Noah's ark: Only a few were recommended from the many available possibilities. In addition, some additional nurturing, similar to that which Noah and later farmers had to provide for their animals, has been recommended.

\section{Notes}

1. Some of the terms are used by certain scholars for a special kind of language planning or language policy (cf. Cluver 1993).

2. Two of the best contributions both pro and contra descriptive linguistics date from 1723, consisting of two works titled "usus imperium" (Fabricius 1723) and "usus tyrannus" (Richey 1723). In short, the question is whether the use is an emperor or a tyrant.

3. The present discussion on policy is partly based on the discussion in Bergenholtz and Johnsen (2006). 
4. The rare examples of the simultaneous occurrence of both terms do not contradict the trend described, particularly as such texts provide neither clear definitions nor distinctions, either because the authors find such provision unnecessary, or because the terms might be perceived as being synonymous (cf. Rosenmeier 2005:115-140).

5. Comments on the Danish and Swedish government language policies appear in Bergenholtz and Johnsen (2006).

6. Similarly, in the case of the communication policy and language policy formulated by and for the same institution (as with the Danish Courts), no mention is made of language policy in the communication policy, although very similar sentences exist in different parts of the language policy issued by the same institution. An example of such similarity can be seen in Undgå lange og falige forklaringer og tal dansk ("Avoid long and specialised explanations containing many specialised terms and speak Danish").

7. All recommended terms appear in bold-face type.

\section{References}

Ager, D. 1996. Language policy in Britain and France. The processes of policy. London and New York: Cassel.

Applera. 2005. Director Communication Policy http://www.applera.com/applera/ applerahome.nsf/cc6ab90fd2809be185256d95006d60f3/AAB3C4CEEFB7C3EA88256 EF9004FC500 (accessed November 2005).

Bathily, A. 2005. Strategic thinking. Community radio in Senegal today. Issues and outlooks. http://www.comminit.com/africa/strategicthinking/st2005/thinking-1053.html (accessed November 2005).

Bergenholtz, H. 1991. Deutsche Grammatiken am Scheideweg. In H. Bergenholtz, A. Dörner, R. Karatas, and G. Meder (eds). Wegweiser durch die Grammatik von Heinrich Bauer. Verzeichnisse und Erläuterungen. Berlin: de Gruyter. pp. 61-89. 
Bergenholtz, H. 2003. User-oriented understanding of descriptive, proscriptive and prescriptive lexicography. Lexikos 13: 65-80.

Bergenholtz, H. 2004. Sprachpolitik: Also: Deutsch sprechen Deutsche in deutschen Landen. Aber warum schreibt man manchmal Deutsch und manchmal deutsch? EliS_e 4/1: 4354. http://www.elise.uni-essen.de/elise/elise_04_01/el_04_01 (accessed November 2005).

Bergenholtz, H., J. Bisgaard, M. Brunsborg, and K.K. Kwichmann. 2003. Sprogpolitik: So ein Ding müssen wir auch haben. Hermes 31: 135-165.

Bergenholtz, H. and M. Johnsen. 2006. Language policy and communication policy - Same same but different? Hermes 37 (in print).

Bergenholtz, H. and S. Tarp. 2005. Política lingüística: Conceptos y definiciones. In Canadian Translators, Terminologists and Interpreters Council (eds). Fifth symposium on translation, terminology and interpretation in Cuba and Canada. http://www.cttic.org./e_publications.htm.

Cameron, D. 1995. Verbal hygiene. London and New York: Routledge.

Centre for Deaf Studies. 2005. CDS communication policy. http://www.bris.ac.uk/deaf/ enquiries/cds_policies/comm_policy (accessed November 2005).

Committee on the Swedish Language. 2002. Speech. Draft action programme for the Swedish language. Summary. Stockholm: Statens offentliga utredningar.

Communication Policy for Danish Courts. 2003. = Domstolsstyrelsen: Kommunikationspolitik for Danske Domstole. http:/www.domstol.dk/HTML/ ublikationer/kommunikationspolitik.pdf (accessed January 2006)

Comtask Report. 1996. Communications 2000: A vision for government communications in South Africa (Comtask Report). October 1996. Final report of the task group on government communications to Deputy President Thabo Mbeki. http://www. cis.gov.za/docs/govcomm/comtask/ (accessed January 2006).

Cooper, R.L. 1989. Language planning and social change. Cambridge, etc.: Cambridge University Press.

Coronel-Molina, S. 1999. Language and literacy planning. http://www.dolphin.upenn.edu/ $\sim$ scoronel/lg-policy.html (accessed January 2006).

Crystal, D. 1992. An encyclopedic dictionary of language and languages. Oxford: Blackwell. 
Danish Dictionary of Linguistics. 1996. J. Cramer, L.A. Henriksen, M. Kunøe, E.V. Larsen, O. Togeby, and P. Widell. 699 varme termer. Leksikon til sprogkundskab. Århus: Aarhus Universitetsforlag.

Danish Medicines Agency. 2005. Communication at the Danish Medicines Agency. http:// www.dkma.dk/1024/visUKLSArtikel.asp?artikelID=5855 (accessed November 2005).

De Cillia, R. 2003. Braucht Österreich eine Sprachenpolitik? In B. Busch and R. de Cillia (eds). Sprachenpolitik in Österreich. Eine Bestandaufnahme. Frankfurt a.M.: Peter Lang. pp. 9-42.

Cluver, V. 1993. A dictionary of language planning terms. Pretoria: University of South Africa.

Eastman, C.M. 1983. Language planning. An introduction. San Francisco: Chandler and Sharp Publishers.

European Court of Auditors. 2002. The Court's communication policies and standards. http://www.eca.eu.int/eca/communication/eca_communication_index_en.htm (accessed November 2005).

Fabricius, J.A. 1723. Usus imperium sine ezceptione assertum oder die unumschränkte Gewalt des Gebrauchs/gleichwie in andern Sprachen/also auch in der Teutschen, behauptet wider die weit aussehenden Neuerungen der SprachLehrenden Malcontenten. In C.F. Reichmanns Poesie der Nieder-Sachsen. Zweyter Theil. Dem vorgedruck einigen zwischen Herrn Doct. Fabricius und Herrn Prof. Richey freundlichgewechselte Streit-Schriften über verschiedene, die Teutsche Sprache betreffende, Puncte. Hamburg: Johann Christoph Kißner (= Poesie der Niedersachen. Hrsg. von Christian Friedrich Weichmann 1721-1738. Bd. 2. Unveränderter Nachdruck: München: Kraus Reprint 1980). pp. 12-26.

Fettes, M. 1997. Language planning and education. In R. Wodak and D. Corson (eds). Encyclopedia of language and education. Volume 1. Language policy and political issues in education. Dordrecht, Boston, and London: Kluwer. pp. 13-22.

Fishman, J.A. 1974a. Language modernization and planning. In J.A. Fishman (ed). Advances in language planning. The Hague: Mouton. pp. 79-102.

Fishman, J.A. 1974b. Language planning and language planning research. In J.A. Fishman (ed). Advances in language planning. The Hague: Mouton. pp. 15-33.

Food and Agricultural Organisation of the United Nations. 1999. Eighty-first Session of the Programme Committee/Ninety-second Session of the Finance Committee Rome, 3-7 
May 1999: Review of FAO language policy. http://www.fao.org/docrep/ meeting/x1516e.htm (accessed November 2005).

Grin, F. 1996. The economics of language: survey, assessment, and prospect. In F. Grin (ed). Economic approaches to language and language planning. [thematic part in] International Journal of the Sociology of Language 121: 17-44.

Hartmann, R.R.K. and G. James. 1998. Dictionary of lexicography. London and New York: Routledge.

Hartmann, R.R.K. and F.C. Stork. 1972. Dictionary of language and linguistics. New York and Toronto: John Wiley and Sons.

Haugen, E. 1959. Planning for a standard language in Modern Norway. Anthropological Linguistics 1: 8-21.

Haugen, E. 1969. Language planning, theory and practice. In A. Grauer (ed). Actes du Xe Congrés International des Linguistes. Bucarest 1967. Bucarest: Editions de L'Academie de la République Socialiste des Roumanie. pp. 701-711.

Jarvad, P. 2001. Det danske sprogs status i 1990'erne med scrlig henblik på domœnetab. Nordisk Ministerråd: København. http://www.valq74pb4dpkmspp0cpp8crh0a1km2 (accessed January 2006).

Jernudd, B.H. 1973. Language planning as a type of language treatment. In J. Rubin and R. Shuy (eds). Language planning: Current issues and research. Washington, D.C.: Georgetown University Press. pp. 11-23.

Johnson, K. and H. Johnson. 1998. Encyclopedic dictionary of applied linguistics. A handbook for language teaching. Oxford: Blackwell.

Kamwangamalu, N.M. 2004. The language planning situation in South Africa. In R.B. Baldauf, Jr, and R.B. Kaplan (eds). Language planning and policy in Africa. Volume 1. Botswana, Malawi, Mozambique and South Africa. Clevedon/Buffalo/Toronto: Multilingual Matters. pp. 197-281.

Kaplan, R.B. and R.B. Baldauf, Jr. 1997. Language planning. From practice to theory. Clevedon: Multilingual Matters.

Karam, F.S. 1974. Toward a definition of language planning. In J.A. Fishman (ed). Advances in language planning. The Hague: Mouton. pp. 103-124.

Kotler, P. and K.L. Keller. 2006. Marketing management. $12^{\text {th }}$ edition. Upper Saddle River, N.J.: Prentice Hall. 
Kulturministeriet. 2003. Sprog på spil - et udspil til en dansk sprogpolitik. København: Kulturministeriet.

Lakoff, R. 1990. Talking power: The politics of language. New York: Basic Books.

Language Policy and Plan for South Africa. 2000. Final draft: Language policy and plan for South Africa. By The Advisory Panel on Language Policy. To The Minister of Arts, Culture, Science and Technology 6 November 2000. http://www.dac.gov.za/about_us/ cd_nat_language/language_policy/Language\%20Policy\%20and\%20Plan\%20for\%20So uth\%20Africa.htm (accessed January 2006).

Language Policy for Danish Courts. 2003. Domstolsstyrelsen: Sprogpolitik for Danmarks domstole. København: Domstolsstyrelsen.

Language Policy in Africa. 1997. Draft recommendations from the Group of Experts. Intergovernmental conference of ministers on language policy in Africa, Harare 20-21 March 1997. In H.E. Wolff (ed). Tied tongues. The African Renaissance as a challenge for language planning. Münster: Lit Verlag. pp. 156-161.

Miller, G.A. 1950. Language engineering. Journal of the Acoustical Society of America 22: 720-725.

Møller Nielsen, S. 2003. Ministeriernes kommunikation. Analyser af danske ministeriers kommunikationspolitikker 2000-2001. København: Københavns Universitet. http:// www.kommunikationsforum.dk/Log/Pol.kom.pdf (accessed November 2005).

National Museum of Australia. 2005. Communication policy. Version 1.0. April 2005. http://www.nma.gov.au/libraries/attachments/corporate_documents/policies/communic ation_policy/files/9457/POL-C-012\%20Communication\%20policy-1.0\%20(public).pdf (accessed January 2006).

Phillipson, R. 2003. English-only Europe? Challenging language policy. London and New York: Routledge.

Politiken 2006-02-04.

Richards, J.C., J. Platt, and H. Platt. 1992. Dictionary of language teaching and applied linguistics. London: Longman.

Richey, M. 1723. Usus Tyrannus precario imperans, oder Vernunft-mäßige Sätze von der Gewalt des Gebrauches in den Sprachen/insonderheit in der Teutschen, ingleichen ob und wie weit man demselben druch Regeln der SprachKunst Einhalt thun könne. In C.F. Reichmanns Poesie der Nieder-Sachsen. Zweyter Theil. Dem vorgedruck einigen zwischen Herrn Doct. Fabricius und Herrn Prof. Richey freundlich-gewechselte Streit- 
Schriften über verschiedene, die Teutsche Sprache betreffende, Puncte. Hamburg: Johann Christoph Kißner (= Poesie der Niedersachen. Hrsg. von Christian Friedrich Weichmann 1721-1738. Bd. 2. Unveränderter Nachdruck: München: Kraus Reprint 1980). pp. 2-11.

Rosenmeier, L. 2005. Få budskabet ud. Om formidling af juridiske tekster. København: Nyt Juridisk Forlag.

Rosholm, G. 2002. Gid kommunikationspolitik var LOV! Anmeldelse af Helle Petersen: Strategisk kommunikation - kvalitetsstyring og måling. In Kommunikationsforum http://www.kommunikationsforum.dk/?articleid=5429 (accessed November 2005).

Rubin, J. and B.H. Jernudd. 1971a. Introduction: Language planning as an element in modernization. In J. Rubin and B.H. Jernudd (eds). Can language be planned? Sociolinguistic theory and practice for developing nations. Honolulu: The University Press of Hawaii. pp. xiii-xxiv.

Rubin, J. and B.H. Jernudd (eds). 1971b. Can language be planned? Sociolinguistic theory and practice for developing nations. Honolulu: The University Press of Hawaii.

Sandøy, H. and L.S. Vikør. 1977. Språkplanlegging - Føresetnader, retningslinjer og følgjer. Mål og Makt 4/77: 12-29.

Sibayan, B.P. 1974. Language policy and literacy in the Philippines. In J.A. Fishman (ed). Advances in language planning. The Hague: Mouton. pp. 221-254.

Tanzania. 1997. National information and communication infrastructure (NICI) policies and plans (e-strategies). http://www.uneca.org/aisi/nici/Tanzania/tanzania.htm. (accessed November 2005).

Tauli, V. 1968. Introduction to a theory of language planning. Uppsala: University of Uppsala Press.

Tauli, V. 1974. The theory of language planning. In J.A. Fishman (ed). Advances in language planning. The Hague: Mouton. pp. 49-67.

Trask, R.L 1997. A student's dictionary of language and linguistics. London, New York, Sydney, and Auckland: Arnold.

Unesco. 1953. The use of vernacular languages in education. Reprinted in H.E. Wolff (ed). 2004. Tied tongues. The African Renaissance as a challenge for language planning. Münster: Lit Verlag 2003: 154-155. 
Utbildnings- och kulturdepartementet. 2005. Bästa språket - en samlad svensk språkpolitik. http://www.regeringen.se/sb/d/5359/a/50761;jsessionid=aEgXq6qmC4eh (accessed November 2005).

Webb, V. 2002. Language in South Africa. The role of language in national transformation, reconstruction and development. Amsterdam and Philadelphia: Benjamins.

Wikipedia. 2006. Language Policy. en.wikipedia.org/wiki/Language_policy (accessed January 2006). 